\title{
Cowpea: a legume crop for a challenging environment
}

\section{Running title: Cowpea for a challenging environment}

\section{Márcia Carvalho ${ }^{1}$, Teresa Lino-Neto ${ }^{2 *}$, Eduardo Rosa ${ }^{1}$ and Valdemar Carnide ${ }^{1,3}$}

${ }^{1}$ Centre for the Research and Technology of Agro-Environment and Biological Sciences (CITAB), University of Trás-os-Montes and Alto Douro (UTAD), 5001-801 Vila Real, Portugal;

${ }^{2}$ BioSystems \& Integrative Sciences Institute (BioISI), Plant Functional Biology Centre, University of Minho, Campus de Gualtar, 4710-057 Braga, Portugal

${ }^{3}$ Department of Genetics and Biotechnology, University of Trás-os-Montes and Alto Douro, UTAD, Quinta dos Prados, 5001-801 Vila Real, Portugal

*Corresponding author: Teresa Lino-Neto, e-mail - tlneto@bio.uminho.pt; phone: +351 253601544; fax: +351 253604319; address: Department of Biology, University of Minho, Campus de Gualtar, 4710-057 Braga, Portugal

\begin{abstract}
Cowpea is a grain legume native from Africa and is a primary source of protein for millions of people in sub-Saharan Africa and other parts of the developing world. The main important characteristics of this crop include the good protein quality with a high nutritional value, the nitrogen-fixing ability, and be more drought- and heat-tolerant than most of its legume relatives. In a research perspective, the studies with cowpea are relatively scarce, despite its relevance to agriculture in the developing world and its resilience to stress. This review provides an overview on different aspects of cowpea, with special emphasis on the molecular
\end{abstract}


markers for assessing genetic diversity, as well as on the biochemical and transcriptomic data to evaluate cowpea drought stress tolerance. The integration of both datasets will be useful for cowpea improvement, since the research on drought stress tolerance is a major interest for this crop in a challenging environment.

\section{Keywords}

Cowpea; genetic diversity; morphological traits; molecular markers; drought stress; gene expression

\section{INTRODUCTION}

Cowpea [Vigna unguiculata (L.) Walp.] is a member of Leguminosae family native from Africa and is currently one of the most important grain legumes growing in tropical and subtropical regions. ${ }^{1-3}$ This legume has been used in human diet as well as forage for animal feeding. For human consumption the most important product is the dry grain that can be consumed boiled, fried (as akara), or steamed (as moi moi), ${ }^{4}$ according to different preparations, on salads, snacks, cakes and others. Also young leaves, fresh pods and fresh seeds have been consumed in some world regions. ${ }^{4,5}$ Green organs could be used as vegetable and are often served boiled, as well as consumed fried or fresh. ${ }^{5}$ One of the most important characteristics of cowpea is the high nutritive content value in all plant parts. ${ }^{3,4,6}$ The dry grain is rich in proteins (23\% to $32 \%$ ), essential amino acids as lysine $(427 \mathrm{mg} / \mathrm{g} \mathrm{N})$, and tryptophan $(68 \mathrm{mg} / \mathrm{g} \mathrm{N})$ although low in the sulphur-containing amino acids. ${ }^{7,8}$ So, cowpea and cereals complement each other in terms of amino acids and consequently a diet combining both provides a balanced protein intake. The presence of both minerals (iron and zinc) and 
vitamins (folic acid and vitamin B) has also been reported to be important to prevent birth defects during the pregnancy stage. ${ }^{3,9,10}$ Dry grain is also high in fibre and low in fat. ${ }^{8}$ Taking into account these advantages, an increase of cowpea production and consumption in the European Union is highly desirable. Currently, the European Union imports from African countries almost all consumed cowpea, more specifically from Niger and Nigeria. During the 2009-2013 period, the world cowpea planting area was 5 million hectares and the production was 12 million tonnes. Africa has been responsible for $95.4 \%$ of worldwide cowpea production, ${ }^{11}$ being the drier savannah and the Sahelian region of West and Central Africa responsible for producing 72\%. Nigeria and Niger are the largest producers with 3.4 and 1.4 million tons, respectively. In contrast, Europe is only responsible for $0.4 \%$ of worldwide cowpea production and the European Union have only produced 463 thousand tonnes during the period 2009-2013. ${ }^{11}$

As revealed by the major producing countries, cowpea has the capacity to grow in low fertility soils, which has much to do with the ability of establishing associations with distinct microorganisms, mainly nitrogen-fixing bacteria (like rhizobia) and vesicular-arbuscular mycorrhizal fungi. Cowpea tolerance to low fertility soils ${ }^{8,12,13}$ and to a wide range of soil $\mathrm{pH},{ }^{14}$ as well as the adaptation of cowpea to high temperatures and drought, ${ }^{15}$ makes this grain legume crop of interest for facing the predicted environmental changes (e.g., increased temperature, reduction of water availability) associated with climate change. This review provides an overview of different issues about genomic and transcriptomic studies in cowpea, with more emphasis to studies related with genetic diversity and cowpea drought stress tolerance that could be useful to integrate in cowpea breeding programs.

\section{CLASSIFICATION AND DESCRIPTION}


The cowpea cultivated form obtained from the Antilles was first described by Linnaeus as Dolichos unguiculatus L., being later classified by Walpers as Vigna unguiculata (L.) Walp.. ${ }^{16}$ This diploid species $(2 n=2 x=22)$ belongs to the division Magnoliophyta, class Magnoliopsida, order Fabales, family Leguminosae, tribe Phaseoleae, genus Vigna. The genus Vigna includes more than 80 species $^{17}$ and was subdivided into six sections, namely, Vigna, Comosae, Macrodontae, Reticulatae, Liebrechtsia, and Catiang. ${ }^{18}$ Vigna unguiculata (L.) Walp. includes annual cowpeas (ssp. unguiculata) and ten wild perennial subspecies (Table 1). ${ }^{19}$ The subspecies unguiculata includes all the domesticated forms (var. unguiculata), as well as the wild and weedy forms [var. spontanea (Schweinf.) Pasquet]. ${ }^{19,20}$ The domesticated forms are subdivided into four cultivar-groups essentially based on seed and pod characters. ${ }^{19,21}$ These cultivar-groups are unguiculata grown as pulse, biflora (catjang) used mainly as forage, sesquipedalis (asparagus bean) grown as a vegetable, and textilis cultivated for the fibres of its long floral peduncles. ${ }^{19}$ Pasquet $^{16}$ also proposed the insertion of melanophthalmus (black-eyed pea) as another cultivar-group.

"Cowpea" is the $V$. unguiculata most popular worldwide name but local names such as black-eyed beans, black-eyed peas, pink-eyes or southern peas (all used in United States of America), 'frijol caupí' (Spanish speaking countries in America), 'lobia' (India), 'caupi' (Brazil), 'caupí' and 'carilla' (Spain), 'niébé' (French speaking countries of Africa) and ‘feijão-frade' (Portugal) are used.

Cowpea is described as an herbaceous warm-season annual plant with a great variability in morphology. This crop is autogamous but around 5\% outcrossing was reported in the cultivated varieties probably due to insect activities. ${ }^{22,17}$ Its growth habit could be prostate (trailing), semi-prostate, semi-erect, erect or climbing, depending mostly on genotype but also on photoperiod and growth conditions, being the pattern of growth determinate or indeterminate. ${ }^{8,23}$ This crop is well adapted to a wide range of soil types from sands to heavy, 
including low fertility soils. ${ }^{24}$ Plants grow in an extensive range of temperatures, being $28{ }^{\circ} \mathrm{C}$ the optimal temperature. Early flowering cowpea can produce a crop of dry grain in only 60 days, while longer season cowpeas may require more than 150 days to produce mature pods, depending on photoperiod. ${ }^{8}$

According to the International Institute of Tropical Agriculture (IITA) and Bioversity International (ex-International Board for Plant Genetic Resources, IBPGR), the leaves can be classified into four categories: sub-globose, sub-hastate, globose and hastate/lanceolate. ${ }^{23}$ Flowers emerge in alternate pairs on racemes at the distal ends of long peduncles, with usually two flowers per inflorescence. Flowers have a short life cycle, opening in the early day and closing at approximately midday, after which they usually wilt and collapse. ${ }^{25}$ Corollas can be purple, mauve-pink, yellow or white. ${ }^{23}$ Each peduncle commonly develops two or three pods and pods differ in size, shape, colour and texture. ${ }^{8}$ They are cylindrical, but could be straight, slightly curved, curved or coiled and when they ripe the colour can vary from yellow to brown or dark purple. ${ }^{23}$ The sub-species/cultivar-group Sesquipedalis (more common in Asia) have very long green pods (40 to $100 \mathrm{~cm}$ ) that are often used as green beans (or snap beans), ${ }^{8}$ while the other groups have standard pods (10 to $25 \mathrm{~cm}$ ). Seeds differ in size and colour, ranging from white, cream, green, buff, red, brown or black and can be kidney, ovoid, crowder, globose or rhomboid and are characteristic by the presence of an eye, due to the different pigmentations encircling the hilum. ${ }^{23}$

Environmental conditions, including photoperiod and growing conditions (temperature, rainfall, etc.), can also affect the plant height and morphology. ${ }^{8,24}$ Cowpea root system is dense and well-developed ${ }^{26}$ and has a beneficial effect on the structure and tilth of the topsoil layer. Most root growth occurs within the topsoil layer, but in drought conditions a long taproot can grow for reaching the deeper moisture in the soil profile. ${ }^{27}$ These 
characteristics furnish cowpea plants with a high resistance to drought in comparison with other legumes.

\section{ORIGIN, DOMESTICATION AND DISTRIBUTION}

Africa was suggested as the centre of origin of cowpea. ${ }^{28}$ This belief was not contested, since wild cowpea plants have been found in tropical Africa and Madagascar, ${ }^{1}$ where it was presumably domesticated since Neolithic age. ${ }^{29}$ Pasquet $^{30}$ suggested that the most likely progenitor of domesticated cowpea is V. unguiculata ssp. unguiculata var. spontanea. For determining the precise domestication site and the cowpea diversity centres, several studies have been performed in the last decades, although a conclusive result has been difficult to reach. Several hypotheses have been proposed for cowpea domestication, such as Ethiopia, ${ }^{1,31,32}$ West Africa, ${ }^{33-37}$ Eastern and Southern Africa. ${ }^{38}$ Coulibaly et al. ${ }^{19}$ using amplified fragment length polymorphisms (AFLPs) and morphologic data concluded that the wild species was originated from Eastern Africa. In this case, domestication should have occurred in Northeastern Africa and the domesticated plant was then probably dispersed to Western Africa. According to $\mathrm{Ng}$ and Padulosi, ${ }^{39}$ West Africa seems to be the centre of diversity of cultivated forms. A 'diffuse' domestication in the African savanna after the dispersal of cereals was also hypothesized. ${ }^{1,40}$ This last hypothesis was presented by Harlan, ${ }^{41}$ who considered that the cowpea was domesticated in the African Non-Center. Whatever the place of domestication, cowpea is an ancient legume that was domesticated by African gatherers, cultivators and farmers from its wild forms in Africa dating back to Neolithic times. ${ }^{2}$ During the Neolithic period, the cowpea was first introduced into India, which was then considered a secondary centre of cowpea genetic diversity. ${ }^{42}$ The spread of cowpea in Asia occurred at the end of Neolithic period (third millennium BC), where the subspecies 
asparagus bean or yardlong ( $V$. unguiculata ssp. sesquipedalis) is still cultivated for long immature pods, ${ }^{43}$ and in America between the sixteenth and seventeenth centuries (AD). ${ }^{44}$ Although some reports suggest that cowpea has been cultivated in Europe at least since the eighteenth century BC and possibly since prehistoric times, ${ }^{19,45}$ others suggest that it was only introduced in Europe around $300 \mathrm{BC}$, where it still remains as a minor crop in the southern part. ${ }^{17}$ From Europe, more specifically from Portugal and Spain, this legume was exported in the seventeenth century to the New World. ${ }^{17,46}$ Other important result was obtained by Fang et $a l .{ }^{46}$ that provided evidences for the common origin of cowpea germplasm from Asia and North America different from the West Africa. However, these authors have mostly used breeding lines and consequently the introgression of extra regional germplasm could have occurred. Huynh et al. $^{47}$ analysing a worldwide collection of cowpea landraces and African ancestral wild cowpeas by using more than 1200 single nucleotide polymorphism (SNP) markers verified that accessions from Asia and Europe were more related to those from western Africa, while accessions from Americas appeared more closely related to those from Eastern Africa.

\section{EVALUATION OF GENETIC DIVERSITY}

Cowpea has been referred as a worldwide crop with more prevalence in tropical areas, displaying a high phenotypic/morphological variability. ${ }^{8}$ Genetic diversity assessment is then useful for the preservation and utilization of germplasm resources, as well as for the improvement of varieties/cultivars. ${ }^{3}$ Genetic diversity can be evaluated using morphological traits, biochemical and molecular markers. Each of these markers has different applications in several areas, such as plant breeding, phylogenetic studies, gene mapping, genetic 
engineering, micropropagation and genetic resources characterization, and can be used individually or combined.

Several studies have been referring the characterization of cowpea by morphological and quantitative traits. ${ }^{16,48-52}$ This characterization is followed by using a set of descriptors: i) parameters related with plant morphology, such as growth habit, leaf type, flower colour, seed shape and colour, and ii) parameters related with plant production, namely the number of pods and seeds per plant and seed weight. Morphological characterization does not require any complex equipment or experiments, being simple and inexpensive to score. These are the reasons responsible for the constant use of morphological traits as a first step for evaluating genetic relationships. The main disadvantage is that the observed characteristics do not exclusively reflect the genotype, but reflects the interaction between genotype and environment. $^{53}$

The first biochemical marker to be used for genetic diversity analysis was the isozyme markers in the 60 's. ${ }^{54}$ These enzymes differ in amino acid sequence and are encoded by different genetic loci (isozymes) or by different alleles at the same locus (allozymes), yet catalyse the same reaction. ${ }^{55}$ Until the end of 80 's, isozymes were the main marker used to analyse the genetic variability and taxonomy in plants, helping to define the phylogenetic relationships and population genetics. Over the years, several studies were developed in cowpea that made use of this biochemical marker. Panella and Gepts ${ }^{56}$ and Vaillancourt et $a l .{ }^{57}$ characterized wild and cultivated accessions of cowpea by using 10 and 26 isoenzyme loci, respectively, and concluded that the genetic diversity in the evaluated collections was low. Besides isozyme markers, seed storage protein profiling is another method used to reveal genetic variation between cowpea cultivars. ${ }^{58-62}$ Often, in these studies, the obtained results were not very conclusive by the lack of domesticated cowpea and progenitor representative samples. 
In comparison with morphological and biochemical markers, DNA molecular markers have a set of characteristics that turn them ideal to several studies such as their highly polymorphic nature and frequent occurrence in the genome, allowing a direct comparison of genetic material in an environmental independent way. ${ }^{54,63}$ DNA-based molecular markers have been extensively used in cowpea genetic diversity research, variety identification, phylogenetic analysis, gene mapping, and resource classifications (Table 2). The first study using amplified fragment length polymorphism (AFLP) markers in cowpea was performed by Coulibaly et al., ${ }^{19}$ in which the genetic relationship among a total of 117 cowpea accessions [including 47 domesticated cowpeas (ssp. unguiculata) and 52 wild and weed annuals (ssp. unguiculata var. spontanea)] was pretended. This study showed that the wild cowpeas were more diverse than domesticated ones, also suggesting an Eastern African origin for the wild taxon. This result was corroborated by Ba et al. ${ }^{2}$ using random amplified polymorphic DNA (RAPD) markers, and by Ogunkanmi et al. ${ }^{64}$ with single sequence repeat (SSR) or microsatellites markers. The variation within and among cowpea populations from different agro-ecological regions and germplasm accessions has been also evaluated using AFLP ${ }^{46}$ and RAPD markers. ${ }^{65-68}$ In addition, RAPD markers were used to eliminate the putative duplicates of Senegal cowpea accessions in a germplasm bank and identify elite varieties. ${ }^{69}$ Currently, SSR is the most frequently used molecular marker in cowpea genetic diversity analyses, namely in cowpea landraces accessions from China, Africa and other Asian countries, ${ }^{70}$ Korea,${ }^{71}$ Ghana, ${ }^{72}$ Southwestern Nigeria, ${ }^{73}$ and Senegal, ${ }^{74}$ where a high genetic diversity was observed. To evaluate the genetic diversity of asparagus bean ( $V$. unguiculata ssp. sesquipedalis) cultivars from different Chinese geographical origins, SSR markers derived from $V$. unguiculata ssp. unguiculata sequences were used, attesting the transferability of SSR markers between these two subspecies. ${ }^{75}$ In all these studies, SSR markers also showed sufficient genetic variance that could be useful for improvement 
strategies in cowpea. Single nucleotide polymorphism (SNP) markers have gained an increasing importance, due to their bi-allelic nature, higher frequency in the genome than SSRs and other markers, and to their easily automated genotyping. ${ }^{76}$ In a study for the characterization of 113 cowpea accessions, comprising 108 from Ghana and five from abroad, 458 SNPs (out of 477) revealed high polymorphism. ${ }^{77}$ The results suggested an unexpected high level of heterozygosity. The chip-based SNP detection technology is being widely used in plant genetic applications. ${ }^{78-80}$ In cowpea, Illumina chip-based SNP detection platforms (GoldenGate and more recently iSelect) have been developed and can be very useful for molecular characterization, ${ }^{77,81}$ genetic diversity analysis ${ }^{47,82}$ and genetic mapping. ${ }^{43,83-85}$ Researchers at the University of California, Riverside, in partnership with institutions from several African countries have designed a 60,000-assay iSelect BeadArray for cowpea that successfully assayed 51,128 SNPs. ${ }^{86}$

The combined use of different molecular markers could better assist the evaluation of genetic diversity. Diouf \& $\mathrm{Hilu}^{87}$ used a combination of RAPD and SSR markers for assessing genetic variability of local cowpea varieties and breeding lines from Senegal and identified 12 polymorphisms due to the broad genome coverage used. The combinations of AFLP and SAMPL (selectively amplified microsatellite polymorphic locus) markers, ${ }^{88}$ as well as AFLP and SSR markers, ${ }^{89}$ were used to determine the genetic variation within and among closely related $V$. unguiculata accessions, while the combined use of RAPD and ISSR markers allowed the evaluation of genetic variations of seven Vigna species. ${ }^{90}$ A combination of molecular and classical markers has been considered essential to turn the results of genetic diversity more reasonable for genetic cowpea breeding and evaluation of germplasm resources. ${ }^{3}$ The combined use of molecular markers (SSR and ISSR) and classical markers (morphological traits) was described to estimate the genetic diversity and relatedness of 23 asparagus bean ( $V$. unguiculata ssp. sesquipedalis) accessions and 7 accessions of a hybrid 
between cowpea (V. unguiculata ssp. unguiculata) and dwarf asparagus bean in Thailand. ${ }^{91}$ Morphological characters were diverse among most accessions, but their exclusive use did not allowed to distinguish between accessions. Indeed, ISSR markers showed higher efficiency for estimating the levels of genetic diversity and relationships among the two subspecies than SSR markers. ${ }^{91}$ The combined use of morphological traits, RAPD and ISSR markers was also employed for discriminating landraces of cowpea scattered from all Algeria regions ${ }^{92}$ and evaluate the genetic variability and relationships between two cowpea cultivars and nine elite genotypes. ${ }^{93}$ Both studies showed that ISSR markers were better linked to morphological variation than RAPD markers.

\section{Genetic mapping and marker-assisted selection}

Currently, the construction of the cowpea genetic map is mainly based on the use of efficient molecular markers, such as SSR and SNP, which show sufficient genetic variability. ${ }^{43,83,84,94-}$ ${ }^{97}$ A consensus genetic linkage map using EST-derived SNPs led to the integration of 928 markers into a cowpea genetic map spanning $680 \mathrm{cM}$ with 11 linkage groups $(0.73 \mathrm{cM}$ of average marker distance). ${ }^{98}$ These authors reported a significant macrosynteny with Glycine max and Medicago truncatula genomes, and some microsynteny with Arabidopsis thaliana genome. The first genetic map of asparagus bean based on SNP and SSR markers was reported by $\mathrm{Xu}$ et al.. ${ }^{43}$ This map consisted of 375 loci mapped on 11 linkage groups, with 191 loci detected by SNP markers and 184 loci by SSR markers. The development of a highdensity genetic map offers a powerful tool for analysing the inheritance of target genes, monitoring specific genes or genomic regions transmitted from parents to progeny. ${ }^{3}$ Using the recently developed Illumina iSelect genotyping assay for cowpea, Muñoz-Amatriain et al. ${ }^{85}$ genotyped five biparental RIL populations and developed a consensus genetic map containing 
over 37,000 SNPs mapped to $\sim 3,200$ bins in $\sim 800 \mathrm{cM}$. These results are being used to genetically anchor an initial whole-genome shotgun (WGS) assembly of the cowpea accession IT97K-499-35. To this assembly, sequences from about 4,000 minimal tiling path BACs are being incorporated with the aim to increase the number of anchored scaffolds and help resolve the order within recombination bins.

The biotechnology based on such genetic maps and use of DNA markers brings a great hope in cowpea breeding, as specific molecular markers could be used to select target traits with marker assisted selection (MAS). ${ }^{17}$ The association of 18 SNPs with seed size in cowpea varieties from Ghana suggested that these molecular markers could be useful for marker assisted breeding of larger seeded cowpea plants. ${ }^{99}$ Performing a RFLP analysis of 29 polymorphic markers, among 14 drought-tolerant genotypes, it was possible to find a correlation between seven RFLP markers and different drought-related cowpea phenotypes. ${ }^{100}$ The additional use of other high-density DNA markers in the genome could speed even more the selection process in breeding programs. For breeding to resistance to the parasitic weed Striga gesnerioides, $\mathrm{SSR}^{101}$ and AFLP ${ }^{102,103}$ markers have been used. Similarly, SNPs have been used to identify markers associated to cowpea resistance to foliar thrip. ${ }^{104}$ The asparagus bean rust disease, caused by the fungus Uromyces vignae, was also associated to a specific AFLP marker that can now be effectively used for MAS. ${ }^{105}$ Sequencing and analysis of the gene-rich hypomethylated portion of the cowpea genome was performed by Timko et al. ${ }^{106}$ More than 250,000 gene-space sequences reads (GSRs) were generated, thus providing a source of functional markers for detailed comparative studies of cowpea with other plant species and positional cloning of key genes of agronomic interest.

\section{TOLERANCE TO DROUGHT STRESS}


Drought is one the most severe environmental stresses with major impact on plant development and productivity thus causing serious agricultural yield losses. ${ }^{107,108}$ Drought tolerance is a complex trait defined as the ability of plants to live, grow, and reasonably produce with limited soil water supply or under periodic water deficiencies. ${ }^{109}$ Mitra $^{110}$ grouped the plant mechanisms used to cope with drought stress into three groups: drought escape, drought avoidance and drought tolerance. Crop plants could use more than a single mechanism to cope with drought stress. One of the most important food legumes in tropical and sub-tropical regions, where drought is a major constraint for production due to low and erratic rainfall, is cowpea. Indeed, some authors pointed cowpea as one of the most tolerant crops to drought, due to its capacity of growing in areas with no irrigation facilities and irregular rainfall. ${ }^{24,111-113}$ This tolerance has been attributed to the three drought tolerance mechanisms, ${ }^{112}$ although several drought avoidance mechanisms were extensively described, including deep rooting, strong stomatal sensitivity, reduced growth rate, leaf area reduction, delayed leaf senescence, hastened or delayed reproductive cycle, osmotic adjustment and sensitive moisture remobilization to the upper leaves and growing tips. ${ }^{109,113}$ Since cowpea has the ability to tolerate severe drought conditions and displays a relatively small nuclear genome size (estimated at $\sim 620 \mathrm{Mb}$ ), this legume has been considered as an ideal model to study the molecular mechanisms of drought tolerance in crops. ${ }^{112}$

\section{Morphological, biochemical and physiological traits for drought}

Changes of morphological, biochemical and physiological traits in response to drought stress for several $V$. unguiculata cultivars have been reported. ${ }^{114-117}$ The root system or rooting pattern are closely related to drought-tolerance mechanisms in legume crops. ${ }^{118,119}$ To evaluate and screen cowpea drought-tolerance, several parameters of the root system have been used, 
such as root length density, rooting depth and root dry matter. ${ }^{119}$ To examine cowpea drought tolerance ability, water potential, relative turgidity, diffusion pressure deficit, chlorophyll stability index measurements, or carbon isotope discrimination are typically evaluated. ${ }^{109,120}$ However, most of these methods have the disadvantage of being slow, laborious, expensive, and influenced by environmental conditions. ${ }^{109,112}$ Slabbert et al. ${ }^{114}$ tested and proposed other methods to screen cowpea for drought tolerance, such as proline accumulation, 2,3,5triphenyltetrazolium chloride (TTC) assays, cell membrane stability (CMS), relative water content (RWC), leaf water potential (LWP), leaf area, chlorophyll $a$ and $b$ contents, chlorophyll fluorescence, carotenoids content, evaluation of anti-oxidative responses through enzyme activities determination [superoxide reductase (SOD), glutathione reductase (GR), ascorbate peroxidase (APX)], as well as the early drought screening at the seedling stage (wooden box technique). Altogether, these methods pretend to evaluate the most typical changes that occur in plants after a drought imposition.

As the complex regulatory processes of drought adaptation involves the control of water flux and cellular osmotic adjustments via the biosynthesis of osmoprotectants, ${ }^{108}$ such compounds determination has often been used for screening tolerant cowpea genotypes. The osmoprotectants are classified into three major groups: amino acids (e.g. proline), polyol/sugars (e.g. trehalose, fructans, mannitol), and quaternary amines (e.g. glycine betaine). ${ }^{121-123}$ However, these compounds are not accumulating in all plant species in sufficient amounts to avoid adverse effects of drought stress. ${ }^{122,124}$ Studies in drought stress cowpea and osmoprotectants are still scarce. But, the application of chitosan in drought stress cowpea plants has been described to allow the maintenance of osmotic balance. ${ }^{125}$

Physiological changes related with photosynthesis and stomatal conductance have also been frequently used in drought evaluation studies. Indeed, one of the processes largely affected by water deficit is photosynthesis, due to a decline of stomatal conductance that 
limits the carbon assimilation, as well as due to biochemical and photochemical adjustments. ${ }^{126,127}$ The dynamics of photosynthesis (A), stomatal conductance (gs) and intrinsic water-use efficiency (WUE=A/gs) were evaluated in 14 cowpea genotypes over a period of drought and post-stress. ${ }^{128}$ Under water stress conditions, a decrease in photosynthesis and stomatal conductance accompanied with an increase in the intrinsic wateruse efficiency was detected in all genotypes, although differences between genotypes were found. ${ }^{128}$ When cowpea genotypes, differing in drought resistance, were subjected to three distinct water stress conditions (unstressed, moderate and severe stressed), an increase on root biomass and a reduction on chlorophyll content were detected with water stress imposition. ${ }^{115}$

One of the main regulators of plant drought tolerance is the abscisic acid (ABA) that, not only regulates many essential processes of plant development, including the inhibition of germination and control of stomatal closure, but also several adaptive responses to a variety of environmental stresses. ${ }^{129,130}$ Kulkarni et al. ${ }^{131}$ studying the response of six cowpea cultivars to drought stress suggested that the intrinsic capacity for ABA synthesis could play an important role in regulating stomatal conductance. ABA accumulation is higher in drought-stressed plants than in unstressed plants. ${ }^{12}$ In cowpea, some studies have been developed to understand the role of ABA in the drought tolerance. ${ }^{132,133}$

As membranes are the key targets of degradative processes induced by drought, membrane integrity parameters have also been used for assessing drought stress severity. A decrease in membrane lipid content was reported under water stress, ${ }^{134}$ which seems to be correlated to the inhibition of lipid biosynthesis and stimulation of lipolytic and peroxidative activities. ${ }^{135,136}$ The degradation of membrane lipids and the enzymatic antioxidant activity seem to be a useful method to evaluate the level of plant drought stress. However, data are still scarce in cowpea. ${ }^{111,114,136-138}$ 
Agbidoco et al. ${ }^{112}$ suggested that the most suitable parameters for screening a large number of cowpea lines for drought tolerance are the measurements of chlorophyll fluorescence, stomatal conductance, $\mathrm{ABA}$ and free proline levels. Besides these parameters, the wooden box screening for drought tolerance at the seedling stage and delayed leaf senescence (DLS) could be interesting to evaluate and determine drought tolerance. Physiological, biochemical and agronomic responses to water deficit at flowering stage of cowpea detected an increase of canopy temperature and proline content, as well as a decrease of gaseous exchanges and starch content that eventually affect the yield components with exception of seed number per pod. ${ }^{139}$

The knowledge transfer between plant species and cultivars should be taken with care, since differences in drought tolerance were detected when evaluating distinct plant species or cultivars. For example, a comparison of physiological responses to drought between Vigna unguiculata and Phaseolus vulgaris demonstrated that both species significantly differ in the responses evaluated by leaf gas exchange parameters. ${ }^{140}$

\section{Drought tolerance genes}

Transcriptomic studies have been developed to identify genes, pathways and processes important in controlling plant response to multiple abiotic or biotic stresses, thus providing candidate targets for stress tolerance improvement. ${ }^{141}$ Many cowpea drought-related genes have been deduced from previously recognized candidate genes for drought tolerance in other related species, and were then confirmed by their differential expression in drought-stressed versus non-stressed cowpea plants. On the other hand, studies on the differential expression of cowpea genes in experimental plants subjected to different levels of water privation have led to the identification of cowpea genes involved in drought responses. ${ }^{112}$ 
Many cowpea genes are now recognized as being involved in drought responses (Table 3). Using a differential screening method, Iuchi et al. ${ }^{142}$ isolated $24 \mathrm{cDNA}$ clones that corresponded to dehydration-induced genes from a cowpea variety (IT84S-2246-4) displaying a high drought tolerance. These cDNA clones represented ten different genes, nine of which were specifically induced by dehydration stress. Five of these drought-associated genes were further characterized (CPRD8, CPRD14, CPRD22, CPRD12 and CPRD46),(142,143) being followed by the description of two additional drought-inducible genes all from the same cowpea variety $(V u N C E D 1$ and $V u A B A 1) .(132) V u N C E D 1$ encodes a 9-cis-epoxycarotenoid dioxygenase that catalyses a key step in ABA biosynthesis, while $V u A B A 1$ encodes a zeaxanthin epoxidase ${ }^{132}$ involved in another important key step of ABA biosynthesis. Indeed, zeaxanthin epoxidase has been reported as required for resistance to osmotic and drought stress, ABA-dependent stomatal closure and regulate the expression of stress-responsive genes. $^{144}$

According to the degradation of membrane lipids that occur under drought stress conditions, ${ }^{134}$ several other cowpea drought-related genes are recognized to be involved on lipid metabolism. El-Maarouf et al. ${ }^{135}$ isolated and characterized the cowpea VuPLD1 gene that encodes a phospholipase $\mathrm{D}$, which is the main enzyme responsible for the droughtinduced degradation of membrane phospholipids. In a drought stress susceptible cultivar, phospholipase D activity and $V u P L D 1$ expression were highly stimulated by drought stress, while remained unchanged in a tolerant cultivar. ${ }^{135}$ From the leaves of the same cultivars, Matos et al. ${ }^{136}$ isolated a VuPAT1 (putative patatin-like) gene that encodes for galactolipid acyl hydrolase. A rapid increase of $V u P A T 1$ expression was also observed in the susceptible cultivar under drought conditions, while the tolerant exhibited lower levels of transcripts. These results suggest that drought stress in cowpea stimulates the hydrolysis of galactolipids, the main components of chloroplast membrane. $V u P A P-\alpha$ and $V u P A P-\beta$ are two cDNAs 
encoding putative phosphatidate phosphatases (PAPs) that were cloned from cowpea leaves by Marcel et al.. ${ }^{145}$ PAP plays a role in the enzymatic cascade that leads to membrane lipid degradation under environmental stresses or senescence. ${ }^{137}$ Marcel et al. ${ }^{145}$ revealed that gene expression of $V u P A P-\alpha$ remained very low during drought treatments, being strongly stimulated after rehydration. On the other hand, $V u P A P-\beta$ expression did not vary in plants submitted to water stress by withholding irrigation, but increased rapidly in air desiccated leaves.

Metabolic and adaptive processes, in which the adaptation to drought stress is included, comprise the regulation of protein degradation through the use of protease-specific inhibitors ${ }^{146}$ and cellular protection against oxidative damage through the regulation of antioxidant enzymes and free radical scavengers. ${ }^{147}$ The expression of cowpea cystatin (cowpea leaf protease inhibitor; $V u C I$ ) gene, evaluated at mRNA (Northern analysis) and protein (Western analysis) levels, suggested that two cystatin transcripts producing two distinct polypeptides would lead to a multiplicity of forms related to multiple biological roles. ${ }^{146}$

A noticeable activation of cowpea antioxidant metabolism has been detected under progressive water stress by studying drought-related genes. The cloning and sequencing of two new cDNAs encoding a putative dual-targeted $(d t G R)$ and a cytosolic $(c G R)$ glutathione reductase (GR) from cowpea leaves was performed by Contour-Ansel et al.. ${ }^{138}$ The expression of both genes in cowpea leaves of drought-sensitive and drought-tolerant plants subjected to different drought stress conditions revealed that up-regulation of $c G R$ expression is directly related to the intensity of stress in both cultivars, but $d t G R$ expression was different in susceptible and resistant cultivars. The results revealed the participation of GR in drought responses of both cowpea cultivars, which in susceptible cultivar involves both GR genes. ${ }^{138}$ The expression of other antioxidant enzyme genes (ascorbate peroxidases; APX) was also studied in cowpea response to progressive drought, rapid desiccation and application of 
exogenous ABA. Four new cowpea cDNAs encoding putative cytosolic (VucAPX), peroxisomal (VupAPX), chloroplastic (stromatic VusAPX) and thylakoidal (VutAPX) ascorbate peroxidases were isolated and characterized. ${ }^{111}$ When the expression levels of $\operatorname{VucAPX}$ and $\operatorname{Vup} A P X$ were followed in drought-tolerant and sensitive cultivars, an increase in steady-state transcripts levels was observed in response to rapid water loss and exogenous ABA treatment in drought-sensitive cultivar, while no significant changes in drought-tolerant cultivar were registered. Also, the VusAPX gene expression was strongly stimulated at low levels of water stress in drought-tolerant cultivar. The higher expression of all these genes in tolerant cultivars, comparatively to sensitive ones, suggested once more that cowpea is a drought-tolerant species compared to other crops, indicating that even the more sensitive cultivars have some level of resistance to water deficits. ${ }^{111}$ Two other well-recognized stressrelated genes, GST (glutathione-S-transferase) and $P R-1$ (pathogenesis-related-protein-1), were identified in cowpea by suppression subtractive hybridization (SSH) using droughttolerant and susceptible lines. ${ }^{148}$ Silva et al. ${ }^{149}$ followed the effect of drought and heat stresses on cowpea nodules by evaluating the differential gene expression, using a cDNA-AFLP approach, and identified 14 differentially expressed nodule stress responsive genes. These genes are involved in different metabolic processes, five (VuNSR4, VuNSR10, VuNSR44, VuNSR47 and VuNSR49) of which were related with the nodule protection under abiotic stress conditions as revealed by their expression levels. ${ }^{149}$

\section{MicroRNA drought regulation}

MicroRNAs (miRNAs) regulate gene expression at posttranscriptional level through the recognition of target RNAs by nearly perfect base complementary. Several functional analyses have demonstrated that miRNAs are involved in a variety of plant developmental 
processes and play important roles in plant resistance to abiotic and biotic stresses. ${ }^{150,151}$ From two cowpea genotypes, one drought-tolerant and another drought-sensitive, 157 miRNAs were identified, 44 of which were drought-associated, being 30 upregulated and 14 downregulated in drought conditions. Cowpea miRNAs from leaves and roots of plants subjected to drought treatment were also identified and validated by real-time-quantitative PCR. ${ }^{152}$ The results demonstrated that the same miRNAs in different tissues respond differently to drought stress. Both studies suggest that miRNAs could play an important role in cowpea response to drought stress by regulating the expression levels of drought-related genes.

\section{CONCLUSION}

Global climate changes have an enormous impact on plant diversity patterns with significant current negative effects. In Europe, Mediterranean countries are the ones where is expected a higher impact of climate changes will be expected, including an increase in drought, high temperatures, and water scarcity. Drought is a critical constraint for agricultural production yield, which is currently expanding worldwide and affecting an increased number of countries. New strategies are thus required to overcome this major challenge in agricultural production systems, such as the development of new farming systems and use of undervalued crop varieties. Due to its natural tolerance to water scarcity conditions and high temperatures, cowpea could be considered as a valued crop for increasingly drought scenarios. Besides drought tolerance, cowpea also presents high levels of protein and the capacity to establishing symbiotic associations with distinct microorganisms (rhizobia and mycorrhizal fungi, mainly) that turns it as an environmentally friendly crop. This legume could also be a useful plant model for understanding the mechanisms involved in drought tolerance. The existence of 
several cowpea varieties and cultivars, displaying different tolerance levels to drought conditions, provides an excellent germplasm resource for identifying new candidate genes involved in responses to drought stress tolerance and also for being used in future breeding programmes. DNA molecular markers have shown to be a good tool for germplasm evaluation and selection of the most interesting drought stress/tolerant genotypes. As the marker assisted selection (MAS) can facilitate the selection of elite germplasm and accelerate plant breeding programs, the identification of the precise position of drought-related known genes and of new candidate genes should be done. The integration of data from phenotype, biochemical and molecular characterization will help to understand the resilience and resistance of cowpea under drought and provide sufficient cowpea knowledge for the development of drought-tolerant varieties. For these reasons, cowpea can also be an important plant model for the development of other crop varieties more drought tolerant.

\section{REFERENCES}

1. Steele WM. Cowpeas, Vigna unguiculata (Leguminosae Papillionatae). In: Simmonds NW, editor. Evolution of Crop Plants. Longman; 1976. p. 183-5.

2. Ba FS, Pasquet RS, Gepts P. Genetic diversity in cowpea [Vigna unguiculata (L.) Walp.] as revealed by RAPD markers. Genet Resour Crop Evol. 2004;51:539-50.

3. Tan H, Tie M, Luo Q, Zhu Y, Lai J, Li H. A review of molecular makers applied in cowpea (Vigna unguiculata L. Walp.) Breeding. J Life Sci. 2012;6:1190-9.

4. Boukar O, Fatokun CA, Roberts PA, Abberton M, Huynh BL, Close TJ, et al. Cowpea. In: De Ron AM, editor. Grain Legumes. NewYork: Springer; 2015. p. 219-50.

5. Singh BB, Ajeigbe HA, Tarawali SA, Fernandez-Rivera S, Abubakar M. Improving the production and utilization of cowpea as food and fodder. F Crop Res. 2003;84(12):169-77. 
6. Sebetha ET, Modi AT, Owoeye LG. Cowpea crude protein as affected by cropping system, site and nitrogen fertilization. J Agric Sci. 2014;7(1):224-34.

7. Singh BB, Fatokun CA, Tarawali SA, Kormawa PM, Tamò M. Recent genetic studies in cowpea. In: Cowpea genetic and Breeding. 2002. p. 3-13.

8. Timko MP, Ehlers JD, Roberts PA. Cowpea. In: Kole C, editor. Genome mapping and molecular breeding in plants: Pulses, sugar and tuber crops. Berlin: Springer-Verlag; 2007. p. 49-67.

9. Nielsen SS, Brandt WE, Singh BB. Genetic variability for nutritional composition and cooking time of improved cowpea lines. Crop Sci. 1993;33(3):469-72.

10. Diouf D. Recent advances in cowpea [Vigna unguiculata (L.) Walp.] " omics " research for genetic improvement. African J Biotechnol. 2011;10(15):2803-10.

11. FAOSTAT. Food and Agriculture Organization of the United Nations - Statistics Division [Internet]. 2016 [cited 2016 Aug 5]. Available from: http://faostat3.fao.org/browse/Q/QC/E

12. Eloward HO., Hall AE. Influence of early and late nitrogen fertilization on yield and nitrogen fixation of cowpea under well-watered and dry field conditions. F Crop Res. 1987; 15:229-44.

13. Timko MP, Singh BB. Cowpea, a multifunctional legume. Genomics Trop Crop Plants. 2008;XXXIII(2):227-58.

14. Fery RL. The cowpea: production, utilization, and research in the United States. Hortic Rev (Am Soc Hortic Sci). 1990;12:197-222.

15. Hall A. Comparative ecophysiology of cowpea, common bean, and peanut. Physiol Biotechnol Integr Plant Breed. 2004;271-326.

16. Pasquet RS. Morphological study of cultivated cowpea (Vigna unguiculata (L.) Walp.) Importance of ovule number and definition of cv gr Melanophthalmus. Agronomie. 
1998;18(1):61-70.

17. Badiane FA, Diouf M, Diouf D. Cowpea. In: Singh M, Bisht IS, Dutta M, editors. Broadening the Genetic Base of Grain Legumes. Springer India; 2014. p. 95-114.

18. Maxted N, Mabuza-Diamini P, Moss H, Padulosi S, Jarvis A, Guarino L. An ecogeographic study: African Vigna. In: An ecogeographic study: African Vigna. Rome: International Plant Genetic Resources Institute; 2004.

19. Coulibaly S, Pasquet RS, Papa R, Gepts P. AFLP analysis of the phenetic organization and genetic diversity of Vigna unguiculata L. Walp. reveals extensive gene flow between wild and domesticated types. Theor Appl Genet. 2002;104(2-3):358-66.

20. Pasquet RS. Classification infraspécifique des formes spontanées de Vigna unguiculata (L.) Walp. (Fabaceae) à partir de données morphologiques. Bull Jard Bot Natl Belgique. 1993;62:127-73.

21. Ng NQ, Maréchal R. Cowpea taxonomy, origin and germplasm. In: Singh SR, Rachie KO, editors. Cowpea research, production and utilization. New York: Wiley; 1985. p. $11-21$.

22. Fery RL. The genetics of cowpea: a review of the world literature. In: Singh SR, Rachie KO, editors. Cowpea research, production and utilization. Chichester: Wiley; 1985. p. 25-62.

23. IBPGR. Descriptors for cowpea. Rome. IBPGR Secretariat; 1983.

24. Ehlers JD, Hall AE. Genotypic classification of cowpea based on responses to heat and photoperiod. Crop Sci. 1996;36(3):673-9.

25. Ige OE, Olotuah OF, Akerele V. Floral Biology and Pollination Ecology of Cowpea. Mod Appl Sci. 2011;5(4):74-82.

26. Pandey RK, Herrera WAT, Pendlton JW. Drought response of grain legumes under irrigation gradient. Yield and yield components. Agron J. 1984;76:549-53. 
27. Valenzuela H, Smith J. Cowpea. Sustain Agric. 2002;SA-GM 6.

28. Richard A. Tentamen florae abyssinicae. Paris: Arthus Bertrand; 1847.

29. Vanderborght T, Baudoin JP. Cowpea [Vigna unguiculata (L.) Walpers]. In: Raemaekers RH, editor. Crop production in tropical Africa. Brussels: Directorate General for International Co-operation; 2001. p. 334-48.

30. Pasquet RS. Genetic relationships among subspecies of Vigna unguiculata (L.) Walp. based on allozyme variation. Theor Appl Genet. 1999;98:1104-19.

31. Vavilov NI. Studies on the origin of cultivated plants. Bull Appl Bot Plant Breed. $1926 ; 16: 1-246$.

32. Pasquet RS. Allozyme diversity of cultivated cowpea (Vigna unguiculata (L.) Walp.). Theor Appl Genet. 2000;101:211-9.

33. Murdock GP. Africa, Its Peoples and Their Culture History. New York: McGraw Hill Book Company; 1959.

34. Faris DG. The origin and evolution of the cultivated forms of Vigna sinensis. Can J Genet Cytol. 1965;6:255-8.

35. Rawal KM. Natural hybridization among weedy and cultivated Vigna unguiculata (L.) Walp. Euphytica. 1975;24:699-707.

36. Vaillancourt RE, Weeden NF. Chloroplast DNA polymorphism suggests a Nigerian center of domestication for the cowpea, Vigna unguiculata (Leguminosae). Am J Bot. 1992;79:1194-9.

37. Ng NQ. Cowpea - Vigna unguiculata (Leguminosae-Papilionoideae). In: Smartt J, Simmonds NW, editors. Evolution of crop plants. 2nd ed. Harlow: Longman; 1995. p. $326-32$.

38. Baudoin JP, Maréchal R. Genetic diversity in Vigna. In: Singh SR, Rachie KO, editors. Cowpea research, production and utilization. Chichester: Wiley; 1985. p. 3-11. 
39. Ng NQ, Padulosi S. Cowpea genepool distribution and crop improvement. In: Ng Q, Perrino P, Attere F, H. Z, editors. Crop Genetic Resources of Africa (vol II). Rome: International Board for Plant Genetic Resources; 1988. p. 161-74.

40. Garba M, Pasquet RS. Isozyme polymorphism within section Reticulatae of genus Vigna (Tribe Phaseoleae: Fabaceae). Biochem Syst Ecol. 1998;26:297-308.

41. Harlan JR. Agricultural origins: centers and non centers. Science (80- ). 1971;174:46874.

42. Pant KK, Chandel K, Joshi B. Analysis of diversity in Indian cowpea genetic resources. SABRAO J. 1982;14:103-11.

43. Xu P, Wu X, Wang B, Liu Y, Ehlers JD, Close TJ, et al. A SNP and SSR based genetic map of asparagus bean (Vigna. unguiculata ssp. sesquipedialis) and comparison with the broader species. PLoS One. 2011 Jan;6(1):e15952.

44. Padulosi S, Ng NQ. Origin, taxonomy, and morphology of Vigna unguiculata (L.) Walp. In: Singh B, Mohan RD, Dashie LK, Jackai L, editors. Advances in cowpea research. Ibadan: International Institute of Tropical Agriculture (IITA) and Japan International Research Center for Agricultural Sciences (JIRCAS); 1997. p. 1-12.

45. Tosti N, Negri V. Efficiency of three PCR-based markers in assessing genetic variation among cowpea (Vigna unguiculata subsp. unguiculata) landraces. Genome. $2002 ; 45: 268-75$.

46. Fang J, Chao CCT, Roberts PA, Ehlers JD. Genetic diversity of cowpea [Vigna unguiculata (L.) Walp.] in four West African and USA breeding programs as determined by AFLP analysis. Genet Resour Crop Evol. 2007;54:1197-209.

47. Huynh B-L, Close TJ, Roberts PA, Hu Z, Wanamaker S, Lucas MR, et al. Gene Pools and the Genetic Architecture of Domesticated Cowpea. Plant Genome. 2013;6(3).

48. Adewale BD, Adeigbe OO, Aremu C. Genetic distance and Diversity among some 
Cowpea (Vigna unguiculata L. Walp) genotypes. Int J Res Plant Sci. 2011;1(2):9-14.

49. Stoilova T, Pereira G. Assessment of the genetic diversity in a germplasm collection of cowpea (Vigna unguiculata (L.) Walp.) using morphological traits. African J Agric Res. 2013;8(2):208-15.

50. Cardona-Ayala CE, Araméndiz-Tais T, Jarma-Orozco A. Genetic variability in cowpea beans lines (Vigna unguiculata L. Walp.). Agronomía. 2013;21(2):7-18.

51. Egbadzor KF, Dadoza M, Danquah EY, Yeboah M, Offei SK, Ofori K. Genetic control of seed size in cowpea (Vigna unguiculata (L.) Walp). Int J Agric Sci. 2013;5(2):36771.

52. Egbadzor KF, Danquah EY, Ofori K, Yeboah M, Offei SK. Diversity in 118 cowpea [Vigna unguiculata (L.) Walp.] accessions assessed with 16 morphological traits. Int J Plant Breed Genet. 2014;8(1):13-24.

53. Magloire N. The genetic, morphological and physiological evaluation of African cowpea genotypes. 2005 .

54. Kumar P, Gupta VK, Misra a K, Modi DR, Pandey BK. Potential of Molecular Markers in Plant Biotechnology. Plant Omi J. 2009;2(4):141-62.

55. De La Vega MP. Biochemical characterization of population. In: Hayward MD, Bosemark NO, Romagosa I, editors. Plant Breeding, Principles and Prospects. London: Chapman \& Hall; 1993. p. 184-200.

56. Panella L, Gepts P. Genetic relationships within Vigna unguiculata (L.) Walp. based on isozyme analyses. Genet Resour Crop Evol. 1992;39:71-88.

57. Vaillancourt R, Weeden NF, Barnard J. Isozyme diversity in the cowpea species complex. Crop Sci. 1993;33:606-13.

58. Rao R, Del Vaglio M, D’Urzo MP, Monti L. Identification of Vigna spp. Through specific seed storage polypeptides. Euphytica. 1992;62(1):39-43. 
59. Panella L, Kami J, Gepts P. Vignin diversity in wild and cultivated taxa of Vigna unguiculata (L.) Walp. (Fabaceae). Econ Bot. 1993;47(4):371-86.

60. Fotso M, Azanza JL, Pasquet R, Raymond J. Molecular heterogeneity of Cowpea (Vigna unguiculata Fabaceae) seed storage proteins. Plant Syst Evol. 1994;191(1):39_ 56.

61. Odeigah PGC, Osanyinpeiu AO. Seed protein electrophoretic characterization of cowpea (Vigna unguiculata) germplasm from IITA gene bank. Genet Resour Crop Evol. 1996;43(6):485-91.

62. Oppong-Konadu E.Y.R., Akromah H.K, Adu-Dapaah OE. genetic diversity withen ghanaian cowpea germplasm based on SDS PAGE of seed proteins.pdf. African Crop Sci J. 2005;13(2):117-23.

63. Weising K, Nybom H, Wolff K, Meyer W. DNA Fingerprinting in Plants and Fungi. Arbor A, editor. Boca Raton: CRC Press; 1995. 1-3 p.

64. Ogunkanmi LA, Ogundipe OT, Ng NQ. Genetic diversity in wild relatives of cowpea (Vigna unguiculata) as revealed by simple sequence repeats (SSR) markers. J Food, Agric Environ. 2008;6(3\&4):263-8.

65. Zannou A, Kossou DK, Ahanchede A, Zoundjihekpon J, Agbicodo E, Struik PC. Genetic variability of cultivated cowpea in Benin assessed by random amplified polymorphic DNA. African J Biotechnol. 2008;7(24):4407-14.

66. Malviya N, Sarangi BK, Yadav M., Yadav D. Analysis of genetic diversity in cowpea (Vigna unguiculata L. Walp.) cultivars with random amplified polymorphic DNA markers. Plant Syst Evol. 2012;298:523-6.

67. Prasanthi L, Geetha B, Jyothi BNR, Reddy KR. Evaluation of genetic diversity in cowpea , Vigna unguiculata (L.) Walp gentotypes using Random Amplified Polymorphic DNA (RAPD). 2012;6(1):22-31. 
68. Patil DM, Sawardekar S V, Gokhale NB, Bhave SG, Sawant SS, Sawantdesai SA, et al. Genetic diversity analysis in cowpea [Vigna unguiculata (L.) Walp.] by using RAPD markers. Int J Innov Biotechnol Biochem. 2013;1(1):15-23.

69. Fall L, Diouf D, Fall-ndiaye MA, Badiane FA, Gueye M. Genetic diversity in cowpea [Vigna unguiculata (L.) Walp.] varieties determined by ARA and RAPD techniques. J Biotechnol. 2003;2(February):48-50.

70. $\mathrm{Xu} \mathrm{YH,} \mathrm{Guan} \mathrm{JP,} \mathrm{Zong} \mathrm{XS.} \mathrm{Genetic} \mathrm{diversity} \mathrm{analysis} \mathrm{of} \mathrm{cowpea} \mathrm{germplasm} \mathrm{resources}$ by SSR. Acta Agron Sin. 2007;33(7):1206-9.

71. Lee JR, Back HJ, Yoon MS, Park SK, Cho HY, Kim CY. Analysis of genetic diversity of cowpea landraces from Korea determined by Simple Sequence Repeats and establishment of a core collection. Korean J Breed Sci. 2009;41(4):369-76.

72. Asare AT, Gowda BS, Galyuon IKA, Aboagye LL, Takrama JF, Timko MP. Assessment of the genetic diversity in cowpea (Vigna unguiculata L. Walp.) germplasm from Ghana using simple sequence repeat markers. Plant Genet Resour. 2010;8(2):142-50.

73. Adetiloye IS, Ariyo OJ, Alake CO, Oduwaye OO, Osewa SO. Genetic diversity of some selected Nigeria cowpea using simple sequence repeats (SSR) marker. African J Agric Res. 2013;8(7):586-90.

74. Badiane FA, Gowda BS, Cissé N, Diouf D, Sadio O, Timko MP. Genetic relationship of cowpea (Vigna unguiculata) varieties from Senegal based on SSR markers. Genet Mol Res. 2012;11(1):292-304.

75. Xu P, Wu X, Wang B, Liu Y, Qin D, Ehlers JD, et al. Development and polymorphism of Vigna unguiculata ssp. unguiculata microsatellite markers used for phylogenetic analysis in asparagus bean (Vigna unguiculata ssp. sesquipedialis (L.) Verdc.). Mol Breed. 2010 Dec 16;25(4):675-84. 
76. Jones ES, Sullivan H, Bhattramakki D, Smith J. A comparison of simple sequence repeat and single nucleotide polymorphism marker technologies for the genotypic analysis of maize (Zea mays L.). Theor Appl Genet. 2007;115:361-71.

77. Egbadzor KF, Ofori K, Yeboah M, Aboagye LM, Opoku-Agyeman MO, Danquah EY, et al. Diversity in 113 cowpea [Vigna unguiculata (L) Walp] accessions assessed with 458 SNP markers. Springerplus. 2014;3(1):541.

78. Muñoz-Amatriaín M., Moscou MJ, Bhat P., Svensson JT, Bartoš J, Suchánková P, Šimková H, et al. An Improved Consensus Linkage Map of Barley Based on FlowSorted Chromosomes and Single Nucleotide Polymorphism Markers. Am Soc Agron. $2011 ; 4(3): 238-49$.

79. Ren J, Chen L, Sun D, You FM, Wang J, Peng Y, et al. SNP-revealed genetic diversity in wild emmer wheat correlates with ecological factors. BMC Evol Biol. 2013;13(1):169.

80. $\mathrm{Xu} \mathrm{Q}$, Yuan $\mathrm{X}$, Wang $\mathrm{S}$, Feng $\mathrm{Y}, \mathrm{Yu} \mathrm{H}$, Wang $\mathrm{Y}$, et al. The genetic diversity and structure of indica rice in China as detected by single nucleotide polymorphism analysis. BMC Genet. 2016;1-8.

81. Pottorff M, Roberts PA, Close TJ, Lonardi S, Wanamaker S, Ehlers JD. Identification of candidate genes and molecular markers for heat-induced brown discoloration of seed coats in cowpea [Vigna unguiculata (L.) Walp]. BMC Genomics. 2014;15(1):328.

82. Xiong H, Shi A, Mou B, Qin J, Motes D, Lu W, et al. Genetic diversity and population structure of cowpea (Vigna unguiculata L. Walp). PLoS One. 2016;11(8):1-15.

83. Muchero W, Diop NN, Bhat PR, Fenton RD, Wanamaker S, Pottorff M, et al. A consensus genetic map of cowpea [Vigna unguiculata (L) Walp.] and synteny based on EST-derived SNPs. Proc Natl Acad Sci U S A. 2009;106(43):18159-64.

84. Lucas MR, Diop N-N, Wanamaker S, Ehlers JD, Roberts P a., Close TJ. Cowpea- 
Soybean synteny clarified through an improved genetic map. Plant Genome. $2011 ; 4(3): 218-25$.

85. Muñoz-Amatriaín M, Mirebrahim H, Xu P, Wanamaker SI, Luo M, Alhakami H, et al. Genome resources for climate-resilient cowpea, an essential crop for food security. Plant J. 2016; doi: 10.1111/tpj.13404

86. Close TJ, Lucas MR, Muñoz-Amatriaín M, Mirebrahim H, Wanamaker S, Barkley NA, et al. A New SNP-Genotyping Resource for Cowpea and Its Deployment for Breeding. In: Plant and Animal Genome XXIII Conference. 2015. p. P0784.

87. Diouf D, Hilu KW. Microsatellites and RAPD markers to study genetic relationships among cowpea breeding lines and local varieties in Senegal. Genet Resour Crop Evol. 2005;52(8):1057-67.

88. Tosti N, Negri V. On-going on-farm microevolutionary processes in neighbouring cowpea landraces revealed by molecular markers. Theor Appl Genet. 2005;110(7):1275-83.

89. Gillaspie AG, Hopkins MS, Dean RE. Determining genetic diversity between lines of Vigna unguiculata subspecies by AFLP and SSR markers. Genet Resour Crop Evol. $2005 ; 52(3): 245-7$.

90. El-hady EAAA, Haiba AAA, El-hamid NRA, Al-ansary AEMF. Assessment of genetic variations in some Vigna species by RAPD and ISSR analysis. New York Sci J. 2010;3(11):120-8.

91. Tantasawat P, Trongchuen J, Prajongjai T, Seehalak W, Jittayasothorn Y. Variety identification and comparative analysis of genetic diversity in yardlong bean (Vigna unguiculata ssp. sesquipedalis) using morphological characters, SSR and ISSR analysis. Sci Hortic (Amsterdam). 2010;124:204-16.

92. Ghalmi N, Malice M, Jacquemin J-M, Ounane S-M, Mekliche L, Baudoin J-P, et al. 
Morphological and molecular diversity within Algerian cowpea (Vigna unguiculata (L.) Walp.) landraces. Genet Resour Crop Evol. 2010;57:371-86.

93. Gajera HP, Domadiya RK, Patel SV, Golakiya BA. Appraisal of RAPD and ISSR markers for genetic diversity analysis among cowpea (Vigna unguiculata L.) genotypes. J Crop Sci Biotechnol. 2014;17(2):79-88.

94. Menendez CM, Hall a E, Gept P. Genetic linkage map of cowpea (Vigna unguiculata) developed from a cross between twi inbred,domesticated lines. Theor Appl Genet. $1997 ; 95: 1210-7$.

95. Ouédraogo JT, Gowda BS, Jean M, Close TJ, Ehlers JD, Hall a E, et al. An improved genetic linkage map for cowpea (Vigna unguiculata L.) combining AFLP, RFLP, RAPD, biochemical markers, and biological resistance traits. Genome. 2002 Feb;45(1):175-88.

96. Andargie M, Pasquet RS, Gowda BS, Muluvi GM, Timko MP. Construction of a SSRbased genetic map and identification of QTL for domestication traits using recombinant inbred lines from a cross between wild and cultivated cowpea $(V$. unguiculata (L.) Walp.). Mol Breed. 2011;28(3):413-20.

97. Pottorff M, Ehlers JD, Fatokun C, Roberts PA, Close TJ. Leaf morphology in Cowpea [Vigna unguiculata (L.) Walp]: QTL analysis, physical mapping and identifying a candidate gene using synteny with model legume species. BMC Genomics. 2012;13(1):234

98. Muchero W, Ehlers JD, Close TJ, Roberts PA. Mapping QTL for drought stressinduced premature senescence and maturity in cowpea [Vigna unguiculata (L.) Walp.]. Theor Appl Genet. 2009;118(5):849-63.

99. Egbadzor K.F., Yeboah M, Danquah E.Y., Ofori K. OSK. Identification of SNP markers associated with seed size in cowpea [Vigna unguiculata (L) Walp]. Int J Plant 
Breed Genet. 2013;7(2):115-23.

100. Muchero W, Ehlers JD, Roberts PA. Seedling stage drought-induced phenotypes and drought-responsive genes in diverse cowpea genotypes. Crop Sci. 2008;48(2):541-52.

101. Sawadogo M, Ouedraogo JT, Gowda BS, Timko MP. Genetic diversity of cowpea (Vigna unguiculata L. Walp.) cultivars in Burkina Faso resistant to Striga gesnerioides. African J Biotechnol. 2010;9(48):8146-53.

102. Ouédraogo JT, Tignegre JB, Timko MP, Belzile FJ. AFLP markers linked to resistance against Striga gesnerioides race 1 in cowpea (Vigna unguiculata). Genome. 2002;45:787-93.

103. Boukar O, Kong L, Singh BB, Murdock L, H.W. O. AFLP and AFLP-derived SCAR markers associated with Striga gesnerioides resistance in cowpea. Crop Sci Soc Am. 2004;44(4):1259-64.

104. Lucas MR, Ehlers JD, Huynh B-L, Diop N-N, Roberts PA, Close TJ. Markers for breeding heat-tolerant cowpea. Mol Breed. 2012 Nov 13;31(3):529-36.

105. Li G, Liu Y, Ehlers JD, Zhu Z, Wu X, Wang B, et al. Identification of an AFLP fragment linked to rust resistance in asparagus bean and its conversion to a SCAR marker. HortScience. 2007;42(5):1153-6.

106. Timko MP, Rushton PJ, Laudeman TW, Bokowiec MT, Chipumuro E, Cheung F, et al. Sequencing and analysis of the gene-rich space of cowpea. BMC Genomics. 2008;9(62):103.

107. Tester $\mathrm{M}$, Langridge $\mathrm{P}$. Breeding technologies to increase crop production in a changing world. Science (80- ). 2010;327(5967):818-22.

108. Golldack D, Li C, Mohan H, Probst N. Tolerance to drought and salt stress in plants: Unraveling the signaling networks. Front Plant Sci. 2014;5(April):151.

109. Singh BB, Matsui T. Cowpea varieties for drought tolerance. In: Fatokun CA, Tarawali 
SA, Singh BB, Kormava PM, Tamo M, editors. Challenges and Opportunities for Enhancing Sustainable Cowpea Production. Internatio. Nigeria: International Institute of Tropical Agriculture; 2002. p. 287-300.

110. Mitra J. Genetics and genetic improvement of drought resistance of crop plants. Curr Sci. $2001 ; 80: 758-63$.

111. D'Arcy-Lameta A, Ferrari-Iliou R, Contour-Ansel D, Pham-Thi AT, Zuily-Fodil Y. Isolation and characterization of four ascorbate peroxidase cDNAs responsive to water deficit in cowpea leaves. Ann Bot. 2006;97(1):133-40.

112. Agbicodo EM, Fatokun CA, Muranaka S, Visser RGF, Linden Van Der CG. Breeding drought tolerant cowpea: Constraints, accomplishments, and future prospects. Euphytica. 2009;167(3):353-70.

113. Cardona-Ayala CE, Jarma-Orozco A. Drought adaptation mechanisms in the cowpea (Vigna unguiculata (L.) Walp.). A review. Revista Columbiana de Ciencias Agrarias. $2013 ; 7(2): 277-288$.

114. Slabbert R, Spreeth M, Krüger GHJ. Drought tolerance, traditional crops and biotechnology: breeding towards sustainable development. South African J Bot. 2004;70:116-23.

115. Hayatu M, Mukhtar FB. Physiological responses of some drought resistant cowpea genotypes (Vigna unguiculata (L.) Walp) to water stress. Bayero J Pure Appl Sci. 2010;3(2):69-75.

116. Cardona, A. C. E.; Jarma, O. A.; Araméndiz, T. H.; Perneth, M. M.; Vergara CCA. Gas exchange and mass distribution of the cowpea (Vigna unguiculata [L.] Walp.) under water deficit. Crop Physiol. 2013;3(31):288-96.

117. Hayatu M, Muhammad SY, Habibu UA. Effect Of Water Stress On The Leaf Relative Water Content And Yield Of Some Cowpea (Vigna Unguiculata (L.) Walp.) Genotype. 
Int J Sci Technol Res. 2014;3(7):148-52.

118. Pandey RN, Dhanasekar P. Morphological features and inheritance of foliaceous stipules of primary leaves in cowpea (Vigna unguiculata). Ann Bot. 2004;94(3):46971.

119. Matsui T, Singh BB. Root Characteristics in cowpea related to drought tolerance at the seedling stage. Exp Agric. 2003;39(1):S0014479703001108.

120. Hall AE, Mutters RG, Hubick KT, Farquhar GD. Genotype differences in carbon isotope discrimination by cowpea under wet and dry field conditions. Crop Sci. 1990;30:300-5.

121. Zhu J. Salt and drought stress signal transduction in plants. Annu Rev Plant Biol. 2002;53:247-73.

122. Farooq M, Wahid A, Kobayashi N, Fujita D, Basra S. Plant drought stress : effects , mechanisms and management. Agron Sustain Dev Springer Verlag. 2009;29(1):185212.

123. Khan MS, Ahmad D, Khan MA. Utilization of genes encoding osmoprotectants in transgenic plants for enhanced abiotic stress tolerance. Electron J Biotechnol. 2015;18(4):257-66.

124. Penna S. Buiding stress tolerance through overproducing trehalose in transgenic plants. Trend Plant Sci. 2003;8:355-7.

125. Farouk S, Ramadan A, Showler AT. Chitosan effects on physiochemical indicators of drought-induced leaf stress in cowpea. Plant Knowl J. 2013;2(4):135-44.

126. Chaves MM, Oliveira MM. Mechanisms underlying plant resilience to water deficits: Prospects for water-saving agriculture. J Exp Bot. 2004;55(407):2365-84.

127. Pinheiro C, Chaves MM. Photosynthesis and drought: Can we make metabolic connections from available data? J Exp Bot. 2011;62(3):869-82. 
128. Kutama AS, Hayatu M, Raliat TM, Binta UB, Abdullahi IK. Screening for some physiological mechanisms in some drought tolerant genotypes of cowpea (Vigna unguiculata (L.) Walp.). Stand Res J Agric Sci. 2014;2(4):59-64.

129. Finkelstein RR, Gampala SS, Rock CD. Abscisic acid signaling in seeds and seedlings. Plant Cell. 2002;14:S15-45.

130. Fujita Y, Fujita M., Satoh R, Maruyama K, Parvez MM, Seki M, et al. AREB1 is a transcription activator of novel ABRE-dependent ABA signaling that enhances drought stress tolerance in Arabidopsis. Am Soc Plant Biol. 2005;17(12):3470-88.

131. Kulkarni MJ, Prasad TG, Sashidhar VR. Genotypic variation in early warning signals from roots in drying soil: intrinsic differences in ABA synthesizing capacity rather than root density determines total ABA message in cowpea (Vigna unguiculata L.). Ann Appl Biol. 2000;136:267-72.

132. Iuchi S, Kobayashi M, Yamaguchi-Shinozaki K, Shinozaki K. A stress-inducible gene for 9-cis-epoxycarotenoid dioxygenase involved in abscisic acid biosynthesis under water stress in drought-tolerant cowpea. Plant Physiol. 2000;123(2):553-62.

133. da Costa RCL, Lobato AKS, da Silveira JAG, Laughinghouse IV HD. ABA-mediated proline synthesis in cowpea leaves exposed to water deficiency and rehydration. Turkish J Agric For. 2011;35(3):309-17.

134. Monteiro de Paula F, Pham Thi AT, Zuily-Fodil Y, Ferrarilliou R, Vieira Da Silva J, Mazliak P. Effect of water stress on biosynthesis and degradation of polyunsaturated lipid molecular species of Vigna unguiculata. Plant Physiol Biochem. 1993;31:707-15.

135. El-Maarouf H, Zuily-Fodil Y, Gareil M, D`Arcy-Lameta A, Pham-Thi AT. Enzymatic activity and gene expression under water stress of phospholipase D in two cultivars of Vigna unguiculata L. Walp. differing in drought tolerance. Plant Mol Biol. 1999;39:1257-65. 
136. Matos AR, D’Arcy-Lameta A, Franca M, Petres S, Edelman L, Kader JC, et al. A novel patatin-like gene stimulated by drought stress encodes a galactolipid acyl hydrolase. FEBS Lett. 2001;491:188-92.

137. Sahsah Y, Campos P, Gareil M, Zuily-Fodil Y, Pham Thi A. Enzymatic degradation of polar lipids in Vigna unguiculata leaves and influence of drought stress. Physiol Plant. 1998;104:577-86.

138. Contour-Ansel D, Torres-Franklin ML, Cruz De Carvalho MH, D'Arcy-Lameta A, Zuily-Fodil Y. Glutathione reductase in leaves of cowpea: Cloning of two cDNAs, expression and enzymatic activity under progressive drought stress, desiccation and abscisic acid treatment. Ann Bot. 2006;98(6):1279-87.

139. Hamidou F, Zombre G, Braconnier S. Physiological and biochemical responses of cowpea genotypes to water stress under glasshouse and field conditions. J Agron Crop Sci. 2007;193(4):229-37.

140. Cruz de Carvalho MH, Laffray D, Louguet P. Comparison of the physiological responses of Phaseolus vulgaris and Vigna unguiculata cultivars when submitted to drought conditions. Environ Exp Bot. 1998;40(3):197-207.

141. Atkinson NJ, Urwin PE. The interaction of plant biotic and abiotic stresses: From genes to the field. J Exp Bot. 2012;63(10):3523-44.

142. Iuchi S, Yamaguchi-Shinozaki K, Urao T, Terao T, Shinozaki K. Novel droughtinducible genes in the highly drought-tolerant cowpea: cloning of cDNAs and analysis of the expression of the corresponding genes. Plant Cell Physiol. 1996;37(8):1073-82.

143. Iuchi S, Yamaguchi-Shinozaki K, Urao T, Shinozaki K. Characterization of two cDNA for novel drought-inducible genes in the highly tolerant cowpea. J Plant Res. 1996;109:415-24.

144. Seo M, Koshiba T. Complex regulation of ABA biosynthesis in plants. Trends Plant 
Sci. $2002 ; 7(1): 41-8$.

145. Marcel GC, Matos A, D’Arcy-Lameta A, Kader JC, Zuily-Fodil Y, Pham-Thi A. Two novel plant cDNAs homologous to animal type-2 phosphatidate phosphatase are expressed in cowpea leaves and are differently regulated by water deficits. Biochem Soc Trans. 2000;28(6):915-7.

146. Diop NN, Kidrič M, Repellin A, Gareil M, D’Arcy-Lameta A, Pham Thi AT, et al. A multicystatin is induced by drought-stress in cowpea (Vigna unguiculata (L.) Walp.) leaves. FEBS Lett. 2004;577(3):545-50.

147. Cruz de Carvalho MH. Drought stress and reactive oxygen species: Production, scavenging and signaling. Plant Signal Behav. 2008;3(3):156-65.

148. Gazendam I, Oelofse D. Isolation of cowpea genes conferring drought tolerance: Construction of a cDNA drought expression library. Water SA. 2007;33(3 special ediction):387-91.

149. da Silva HAP, de Souza Galisa P, da Silva Oliveira RS, Vidal MS, Simões-Araújo JL. Expressão gênica induzida por estresses abióticos em nódulos de feijão-caupi. Pesqui Agropecu Bras. 2012;47(6):797-807.

150. Barrera-Figueroa BE, Gao L, Diop NN, Wu Z, Ehlers JD, Roberts PA, et al. Identification and comparative analysis of drought-associated microRNAs in two cowpea genotypes. BMC Plant Biol. 2011;11(1):127.

151. Khraiwesh B, Zhu J-K, Zhu J. Role of miRNAs and siRNAs in biotic and abiotic stress responses of plants. Biochim Biophys Acta. 2012;1819(2):137-48.

152. Shui XR, Chen ZW, Li JX. MicroRNA prediction and its function in regulating drought-related genes in cowpea. Plant Sci. 2013;210:25-35.

153. Ouédraogo JT, Maheshwari V, Berner DK, St-Pierre CA, Belzile F, Timko MP. Identification of AFLP markers linked to resistance of cowpea (Vigna unguiculata L.) 
to parasitism by Striga gesnerioides. Theor Appl Genet. 2001;102(6-7):1029-36.

154. Rodrigues MA, Santos CA, Santana JR. Mapping of AFLP loci linked to tolerance to cowpea golden mosaic virus. Genet Mol Res. 2012;11(4):3789-97.

155. Fatokun CA, Menancio-Hautea DI, Danesh D, Young ND. Evidence for orthologous seed weight genes in cowpea and mung bean based on RFLP mapping. Genetics. 1992;132(3):841-6.

156. Myers GO, Fatokun C a., Young ND. RFLP mapping of all aphid resistance gene in cowpea (Vigna unguiculata L Walp). Euphytica. 1996;91(2):181-7.

157. Krasova-Wade T, Ndoye I, Braconnier S, Sarr B, Lajudie P, Neyra M. Diversity of indigenous bradyrhizobia associated with three cowpea cultivars (Vigna unguiculata (L). Walp.) grown under limited and favorable water conditions in Senegal (West Africa). African J Biotechnol. 2003;2(1):13-22.

158. Nkongolo KK. Genetic characterization of Malawian cowpea (Vigna unguiculata (L.) Walp) landraces: Diversity and gene flow among accessions. Euphytica. 2003;129(2):219-28.

159. Abdel-Sabour AG, Obiadalla-Ali HA, AbdelRehim KA. Genetic and chemical analyses of six cowpea and two Phaseolus bean species differing in resistance to weevil pest. J Crop Sci Biotechnol. 2010;13(1):53-60.

160. Gupta SK, Gopalakrishna T. Development of unigene-derived SSR markers in cowpea (Vigna unguiculata) and their transferability to other Vigna species. Genome. 2010;53(7):508-23.

161. Gioi TD, Boora KS, Chaudhary K. Identification and characterization of SSR markers linked to yellow mosaic virus resistance gene(s) in cowpea (Vigna unguiculata). Int J Plant Res. 2012;2(1):1-8.

162. Bansal R, Gupta SK, Gopalakrishna T. Transferability of cowpea and azuki bean 
derived SSR markers to other Vigna species. J Food Legum. 2012;25(4):273-8.

163. Ali ZB, Yao KN, Odeny DA, Eltahir IM. Assessing the genetic diversity of cowpea [Vigna unguiculata (L.) Walp.] accessions from Sudan using simple sequence repeat (SSR) markers. African J Plant Sci. 2015;9(7):293-304.

164. Huynh BL, Ehlers JD, Ndeve A, Wanamaker S, Lucas MR, Close TJ, et al. Genetic mapping and legume synteny of aphid resistance in African cowpea (Vigna unguiculata L. Walp.) grown in California. Mol Breed. 2015;35(1).

165. Xu P, Wu X, Muñoz-Amatriaín M, Wang B, Wu X, Hu Y, et al. Genomic regions, cellular components and gene regulatory basis underlying pod length variations in cowpea ( V. unguiculata L. Walp). Plant Biotechnol J. 2016;1-11.

\section{TABLES}

Table 1 - Taxonomic classification of cowpea. 


\begin{tabular}{|c|c|c|c|}
\hline Species & Subspecies & Variety & Cultivar group \\
\hline \multirow[b]{3}{*}{ Vigna unguiculata } & & spontanea & \\
\hline & unguiculata & unguiculata & $\begin{array}{l}\text { unguiculata } \\
\text { biflora } \\
\text { sesquipedalis } \\
\text { textilis } \\
\text { melanophthalmus }\end{array}$ \\
\hline & $\begin{array}{l}\text { baoulensis } \\
\text { burundiensis } \\
\text { letozeyi } \\
\text { aduensis } \\
\text { pawekiae } \\
\text { dekindtiana } \\
\text { stenophylla } \\
\text { tenuis } \\
\text { alba } \\
\text { pubescens }\end{array}$ & & \\
\hline
\end{tabular}

Table 2 - DNA-based molecular markers that have been used for specific cowpea studies.

\section{Molecular}

Marker
Sub-species
Objective

References

\begin{tabular}{llll}
\hline AFLP $\quad$ V. unguiculata ssp. unguiculata & Markers linked to cowpea $\quad$ Ouédraogo et al.,
\end{tabular}




\begin{tabular}{|c|c|c|c|}
\hline & & parasitism resistance & $2001^{153}$ \\
\hline & V. unguiculata ssp. unguiculata & Phenetic organization and & Coulibaly et al., \\
\hline & V. unguiculata ssp. spontanea & genetic diversity & $2002^{19}$ \\
\hline & V. unguiculata ssp. unguiculata & Genetic diversity & Fang et al., $2007^{46}$ \\
\hline & V. unguiculata ssp. unguiculata & Markers linked to cowpea & Rodrigues et al., \\
\hline & & golden mosaic virus & $2012^{154}$ \\
\hline \multirow{9}{*}{ RFLP } & V. unguiculata ssp. unguiculata & Markers linked to orthologous & Fatokun et al., $1992^{155}$ \\
\hline & Vigna radiata & seed weight genes & \\
\hline & V. unguiculata ssp. unguiculata & Markers linked to aphid & Myers et al., $1996^{156}$ \\
\hline & & resistance gene & \\
\hline & \multirow[t]{2}{*}{ V. unguiculata ssp. unguiculata } & Diversity of indigenous & Krasova-Wade et al., \\
\hline & & bradyrhizobia & $2003^{157}$ \\
\hline & \multirow[t]{3}{*}{ V. unguiculata ssp. unguiculata } & Markers linked to genotypic & Muchero et al., \\
\hline & & and phenotypic responses to & $2008^{100}$ \\
\hline & & seedling-stage drought & \\
\hline \multirow{13}{*}{ RAPD } & V. unguiculata ssp. unguiculata & Genetic diversity & Fall et al., $2003^{69}$ \\
\hline & V. unguiculata ssp. unguiculata & Genetic relatedness and gene & Nkongolo, $2003^{158}$ \\
\hline & & flow & \\
\hline & V. unguiculata ssp. unguiculata & Genetic diversity & Ba et al., $2004^{2}$ \\
\hline & V. unguiculata ssp. spontanea & & \\
\hline & Vigna unguiculata ssp. & Genetic diversity & Zannou et al., $2008^{65}$ \\
\hline & unguiculata & & \\
\hline & V. unguiculata ssp. unguiculata & Genetic diversity and markers & Abdel-Sabour et al., \\
\hline & Phaseolus vulgaris & linked to cowpea resistance to & $2010^{159}$ \\
\hline & & pests weevil pests & \\
\hline & V. unguiculata ssp. unguiculata & Genetic diversity & Malviya et al., $2012^{66}$ \\
\hline & V. unguiculata ssp. unguiculata & Genetic diversity & Prasanthi et al., $2012^{67}$ \\
\hline & V. unguiculata ssp. unguiculata & Genetic diversity & Patil et al., $2013^{68}$ \\
\hline & V. unguiculata ssp. unguiculata & Genetic diversity and & Li et al., $2001^{105}$ \\
\hline & V. unguiculata ssp. dekindtiana & relationships & \\
\hline & var. pubescens & & \\
\hline & V. unguiculata ssp. unguiculata & Genetic diversity & $\mathrm{Xu}$ et al., $2007^{70}$ \\
\hline & V. unguiculata ssp. dekindtiana & Genetic diversity & Ogunkanmi et al., \\
\hline SSR & V. unguiculata ssp. ovata & & $2008^{64}$ \\
\hline & V. unguiculata $\mathrm{ssp}$. & & \\
\hline & kgalagadensis & & \\
\hline & V. unguiculata ssp. rhomboidea & & \\
\hline & V. unguiculata ssp. Pubescens & & \\
\hline & V. unguiculata ssp. mensensis & & \\
\hline
\end{tabular}


$V$. unguiculata ssp. grandiflora

$V$. unguiculata ssp. congolensis

$V$. unguiculata ssp. unguiculata

$V$. unguiculata ssp. unguiculata

$V$. vexillata

V. umbellate

V. glabrescens

V. aconitifolia

V. trilobata

$V$. angularis

$V$. radiata

$V$. radiata

$V$. radiate var. setulosa

V. radiate var. sublobata

V. mungo

$V$. mungo var. silvestres

$V$. unguiculata ssp. unguiculata

V. unguiculata ssp. sesquipedalis

V. unguiculata ssp. unguiculata

V. unguiculata ssp. unguiculata

$V$. unguiculata ssp. unguiculata

V. unguiculata ssp. unguiculata

V unguiculata ssp. unguiculata

$V$. unguiculata ssp. unguiculata

V. unguiculata ssp. unguiculata

\section{V. unguiculata ssp. unguiculata}

V. unguiculata ssp. unguiculata

unguiculata ssp. unguiculata

SNP

Glycine max

$V$. unguiculata ssp. unguiculata

V. unguiculata ssp. unguiculata
Genetic diversity

Lee et al., $2009^{71}$

Genetic diversity

Genetic diversity and SSR

transferability between Vigna

species

Asare et al., 201072

Gupta and

Gopalakrishna,

$2010^{160}$

Genetic diversity of cowpea

Sawadogo et al.,

cultivars resistant to Striga

$2010^{101}$

gesnerioides

Genetic diversity and SSR

Xu et al., $2010^{75}$

transferability between subspecies

Genetic distance and diversity

Adewale et al., $2011^{48}$

Genetic map and identification of QTLS

Markers linked to Yellow

Gioi et al., $2012^{161}$

Mosaic Virus Resistance genes

SSR transferability to other

Bansal et al., $2012^{162}$

Vigna species

Genetic diversity

Badiane et al., $2012^{74}$

Genetic diversity

Adetiloye et al.,

$2013^{73}$

Genetic diversity

Ali et al. $2015^{163}$

Consensus genetic linkage

Muchero et al., $2009^{83}$

maps

Linkage mapping and synteny

Lucas et al., $2011^{84}$ to other legumes

Markers linked to resistance to

Lucas et al., $2012^{104}$ foliar thrips

Gene pool structure
Huynh et al., $2013^{47}$ 
V. unguiculata ssp. dekindtiana Phylogenetic relantioships

V. unguiculata ssp. unguiculata Markers linked to seed size

Genetic diversity

Genetic mapping and synteny

of aphid resistance

V. unguiculata ssp. unguiculata Genetic diversity and

population structure

V. unguiculata ssp. unguiculata

V. unguiculata ssp. spontanea

$V$. unguiculata ssp. sesquipedalis
Consensus genetic map

Muñoz-Amatriaín et

al. $2016^{85}$

Pod length QTLs

Xu et al. $2016^{165}$
Egbadzor et al., $2013^{99}$

Egbadzor et al., $2014^{52}$

Huynh et al., $2015^{164}$

Xiong et al. $2016^{82}$ 
Table 3 - Genes identified as being involved in drought tolerance in cowpea.

\begin{tabular}{|c|c|c|c|}
\hline $\begin{array}{l}\text { Gene } \\
\text { designation }\end{array}$ & $\begin{array}{l}\text { Code } \\
\text { number }\end{array}$ & Gene function & Author \\
\hline CPRD\& & D83970 & Response to dehydration stress & Iuchi et al. 1996 (142) \\
\hline CPRD14 & D83971 & Response to dehydration stress & Iuchi et al. 1996(142) \\
\hline CPRD22 & D83972 & Response to dehydration stress & Iuchi et al. 1996(142) \\
\hline CPRD12 & D88121 & Response to dehydration stress & Iuchi et al. 1996(143) \\
\hline CPRD46 & D88122 & $\begin{array}{l}\text { Neoxanthin cleavage enzyme involved in } \\
\text { ABA biosynthesis }\end{array}$ & Iuchi et al. 1996(143) \\
\hline$V u N C E D 1$ & AB030293 & $\begin{array}{l}\text { 9-Cis-epoxycarotenoid dioxygenase involved } \\
\text { in a key step of ABA biosynthesis }\end{array}$ & Iuchi et al. 2000(132) \\
\hline$V u A B A 1$ & AB030295 & $\begin{array}{l}\text { Zeaxanthin epoxidase involved in early step } \\
\text { of ABA biosynthesis }\end{array}$ & Iuchi et al. 2000(132) \\
\hline VuPLD1 & U92656 & $\begin{array}{l}\text { Putative phospholipase } \mathrm{D} \text {, a major lipid- } \\
\text { degrading enzyme in plant }\end{array}$ & El-Maarouf et al.1999(135) \\
\hline$V u P A P-\alpha$ & AF165891 & $\begin{array}{l}\text { Putative phosphatidate phosphatase, } \\
\text { important for the enzymatic cascade leading } \\
\text { to membrane lipid degradation under } \\
\text { environmental stresses or senescence }\end{array}$ & Marcel et al. 2000(145) \\
\hline$V u P A P-\beta$ & AF171230 & $\begin{array}{l}\text { Putative phosphatidate phosphatase, } \\
\text { important for the enzymatic cascade leading } \\
\text { to membrane lipid degradation under } \\
\text { environmental stresses or senescence }\end{array}$ & Marcel et al. 2000 (145) \\
\hline$V u P A T 1$ & AF193067 & $\begin{array}{l}\text { Galactolipid acyl hydrolase involved in } \\
\text { membrane degradation induced by drought } \\
\text { stress }\end{array}$ & Matos et al.2001(136) \\
\hline$V u C 1$ & AF278573 & $\begin{array}{l}\text { Protein inhibitor of cysteine proteinase } \\
\text { belonging to the papain family }\end{array}$ & Diop et al. 2004(146) \\
\hline$d t G R$ & DQ267474 & $\begin{array}{l}\text { Dual-targeted glutathione reductase, a key } \\
\text { enzyme involved in detoxification of AOS }\end{array}$ & $\begin{array}{l}\text { Contour-Ansel et al. } \\
\text { 2006(138) }\end{array}$ \\
\hline$c G R$ & DQ267475 & $\begin{array}{l}\text { Cytosolic glutathione reductase, a key } \\
\text { enzyme involved in detoxification of AOS }\end{array}$ & $\begin{array}{l}\text { Contour-Ansel et al. } \\
\text { 2006(138) }\end{array}$ \\
\hline$V u c A P X$ & U61379 & $\begin{array}{l}\text { Cytosolic ascorbate peroxidase, a key } \\
\text { enzyme involved in detoxification of AOS }\end{array}$ & $\begin{array}{l}\text { D'Arcy-Lameta et al. } \\
\text { 2006(111) }\end{array}$ \\
\hline Vup $A P X$ & AY466858 & $\begin{array}{l}\text { Peroxisomal ascorbate peroxidase, a key } \\
\text { enzyme involved in detoxification of AOS }\end{array}$ & $\begin{array}{l}\text { D'Arcy-Lameta et al. } \\
\text { 2006(111) }\end{array}$ \\
\hline Vus $A P X$ & AY484493 & $\begin{array}{l}\text { Stromatic ascorbate peroxidase, a key } \\
\text { enzyme involved in detoxification of AOS }\end{array}$ & $\begin{array}{l}\text { D'Arcy-Lameta et al. } \\
\text { 2006(111) }\end{array}$ \\
\hline VutAPX & AY484492 & Thylakoidal ascorbate peroxidase, a key & D'Arcy-Lameta et al. \\
\hline
\end{tabular}


GST

PR-1

\begin{tabular}{lll}
$\boldsymbol{V u N S R 4}$ & ABA55727.1 & Digalactosildiacilglicerol sintase 1 \\
$\boldsymbol{V u N S R 1 0}$ & AAC49405.1 & Kinase protein calcium dependent \\
$\boldsymbol{V u N S R 4 4}$ & BAA13541.1 & CPRD12 protein \\
$\boldsymbol{V u N S R 4 7}$ & BAA12161.1 & CPRD12 protein \\
$\boldsymbol{V u N S R 4 9}$ & BAB12160.1 & CPRD8 protein (“old yellow" enzyme) \\
\hline
\end{tabular}

2006(111)

Gazendam and Oelofse 2007(148)

Gazendam and Oelofse 2007(148)

Silva et al. 2012(149)

Silva et al. 2012(149)

Silva et al. 2012(149)

Silva et al. 2012(149)

Silva et al. 2012(149) 